\title{
REPRODUCTIVE AND MATERNAL PERFORMANCE IN THE MOUSE FOLLOWING REMOVAL OF THE OLFACTORY BULBS
}

\author{
R. GANDELMAN, M. X. ZARROW AND V. H. DENENBERG \\ Department of Biobehavioral Sciences, University of Connecticut, \\ Storrs, Connecticut 06268, U.S.A.
}

(Received 11th August 1971, accepted 11th October 1971)

Removal of the olfactory bulbs in pregnant and non-pregnant mice has been shown to lead to a loss of maternal behaviour (Gandelman, Zarrow, Denenberg $\&$ Myers, 1971). Cannibalism of the young occurs in practically all cases, and in the few instances when cannibalism does not take place, the young invariably die from neglect. In mice, therefore, the olfactory system must be functional for maternal behaviour to occur. By contrast, data obtained from the rat indicate that no one sensory system is necessary for the exhibition of maternal behaviour (Beach \& Jaynes, 1956).

In our original experiment (Gandelman, Zarrow, Denenberg \& Myers, 1971), multiparous mice were bulbectomized on Day 12 of gestation, allowed to litter, and were killed immediately after the death of their young in order to verify the brain lesions. It was not known, therefore, whether multiple experiences with pregnancy and parturition occurring subsequent to olfactory bulb removal could overcome the debilitating effect of the lack of olfaction upon maternal behaviour, or whether another sensory system might eventually assume the rôle originally played by the olfactory system. The present experiment investigated this hypothesis.

Twelve, 60-day-old, nulliparous mice of the Rockland-Swiss albino strain had both olfactory bulbs removed. The operation consisted of drilling a 2-mm hole in the skull over the bulbs and removing the tissue by aspiration. The animals were then housed individually in $5 \times 7 \times 11$ in. translucent cages and allowed free access to food and water. Since it has been shown that sham operations do not affect maternal behaviour in 'mice (Gandelman, Zarrow, Denenberg \& Myers, 1971; Zarrow, Gandelman \& Denenberg, 1971), such controls were not employed.

Five days after surgery, one adult male Rockland-Swiss albino mouse was placed in to each cage and the females were checked every morning for the presence of a vaginal plug. After a plug was discovered, the male was removed and the female was left in isolation throughout pregnancy, parturition and the lactation period. During lactation, the females and their young were observed twice a day until the death of the offspring, after which the male was returned to the female's cage. If a vaginal plug was not found within 2 weeks, the male was removed and replaced by another male. If a vaginal plug was not found within 7 days after the second male was introduced, the female was killed and its 
brain was macroscopically examined to determine the presence or absence of olfactory tissue.

Examination of the brain revealed complete bilateral removal of the olfactory bulbs with little if any damage to the frontal cortex in all mice. General health and activity did not appear to be affected by removal of the bulbs. From their response to handling, the animals did not appear to be hyper-irritable.

Table 1 shows the number of times each subject became pregnant, the length of time between bulbectomy and the last parturition, and the response of each animal toward its young. The mean number of pregnancies was $2 \cdot 7$. Behaviour intimately associated with parturition, such as eating of the placenta and cleaning of the young, were displayed by all subjects. However, as seen in Table 1, in no case did an animal care for its young. Cannibalism of the entire litter was the predominant response, and this occurred within $36 \mathrm{hr}$ after parturi-

\section{TABLE 1}

MATERNAL BEHAVIOUR TOWARD YOUNG EXHIBITED BY BULBECTOMIZED MICE AS A FUNCTION OF THE NUMBER OF PREGNANGIES

\begin{tabular}{|c|c|c|c|c|c|}
\hline \multirow[b]{2}{*}{ Subject } & \multirow[b]{2}{*}{ Days* } & \multicolumn{4}{|c|}{ Pregnancy } \\
\hline & & 1 & 2 & 3 & 4 \\
\hline $\begin{array}{r}1 \\
2 \\
3 \\
4 \\
5 \\
6 \\
7 \\
8 \\
9 \\
10 \\
11 \\
12\end{array}$ & $\begin{array}{l}74 \\
52 \\
89 \\
91 \\
74 \\
49 \\
92 \\
67 \\
61 \\
31 \\
98 \\
64\end{array}$ & $\begin{array}{c}\mathrm{G} \\
\mathrm{I} / \mathrm{C} \\
\mathrm{G} \\
\mathrm{G} \\
\mathrm{G} \\
\mathrm{G} \\
\mathrm{G} \\
\mathrm{G} \\
\mathrm{G} \\
\mathrm{C} \\
\mathrm{G} \\
\mathrm{G}\end{array}$ & $\begin{array}{c}\mathrm{C} \\
\mathrm{C} \\
\mathrm{I} \\
\mathrm{C} \\
\mathrm{C} \\
\mathrm{C} \\
\mathrm{I} / \mathrm{C} \\
\mathrm{C} \\
\mathrm{C} \\
\mathrm{C} \\
\mathrm{C}\end{array}$ & $\begin{array}{l}\mathbf{C} \\
\mathbf{C} \\
\mathbf{C}\end{array}$ & C \\
\hline
\end{tabular}

$\mathrm{C}=$ cannibalism; $\mathrm{I}=$ ignored young completely.

* This denotes the number of days elapsing between olfactory bulb removal and birth of the female's last litter.

tion, with one exception. This one animal failed to retrieve her young but did nurse them for 4 days, though all of them were found dead and partly eaten on the morning of the 5 th day.

These results repeat and extend those of Gandelman, Zarrow, Denenberg \& Myers (1971) by showing that multiple experiences with pregnancy and parturition occurring after olfactory bulb removal do not ameliorate the debilitating effect of bulbectomy upon maternal behaviour. Previously (Gandelman, Zarrow, Denenberg \& Myers, 1971; Zarrow et al., 1971), it had been shown that olfactory bulb removal after pregnancy or after parturition also eliminates maternal behaviour. Thus, the effects upon maternal behaviour produced by removal of the olfactory bulbs cannot be modified by experiencing pregnancy and parturition either before or after the bulbs are removed.

Superficially, these results would seem to indicate that mating behaviour was 
unimpaired following removal of the olfactory bulbs. However, the need for olfactory bulbs in order to have mating behaviour appears to vary with different species. Mating behaviour has been described in the bulbectomized rat, and it has been stated that this behaviour may occur even when olfactory stimuli are missing (Aron, Ross \& Asch, 1970).

Nevertheless, it is likely that olfactory bulb removal affected the reproductive function since the bulbectomized mice only produced an average of 2.7 litters. Normal females from our colony are routinely capable of producing five litters. Whitten (1956) has shown that removal of the olfactory bulbs in 6- to 7-week old mice leads to gonadal atrophy within 6 weeks. In order to verify Whitten's finding, nine 70-day-old virgin female Rockland-Swiss

TABLE 2

UTERINE AND OVARIAN WEIGHT OF BULBECTOMIZED

AND NORMAL MICE

\begin{tabular}{|c|c|c|c|c|}
\hline & \multirow{2}{*}{$\begin{array}{c}\text { Body wt } \\
(\mathrm{g})\end{array}$} & \multicolumn{2}{|c|}{ Absolute wt $(\mathrm{mg})$} & \multirow{2}{*}{$\begin{array}{c}\text { Relative } \\
\text { ovarian wt }\end{array}$} \\
\hline & & Ovary & Uterus & \\
\hline Bulbectomized & $\begin{array}{l}32 \cdot 0 \\
31 \cdot 0 \\
31 \cdot 4 \\
35 \cdot 2 \\
39 \cdot 8 \\
40 \cdot 2 \\
36 \cdot 2 \\
30.9 \\
39 \cdot 4\end{array}$ & $\begin{array}{l}15 \cdot 8 \\
14 \cdot 3 \\
16 \cdot 9 \\
15 \cdot 2 \\
11.5 \\
17.7 \\
21 \cdot 8 \\
11.8 \\
16.7\end{array}$ & $\begin{array}{r}160 \cdot 0 \\
134 \cdot 8 \\
139 \cdot 1 \\
156 \cdot 1 \\
70 \cdot 4 \\
117 \cdot 8 \\
326 \cdot 5 \\
73 \cdot 6 \\
268 \cdot 0\end{array}$ & $\begin{array}{l}0.49 \\
0.46 \\
0.54 \\
0.43 \\
0 \cdot 29 \\
0.44 \\
0 \cdot 60 \\
0.38 \\
0.42\end{array}$ \\
\hline Mean & $35 \cdot 12$ & $15 \cdot 74$ & $160 \cdot 70$ & 0.450 \\
\hline Normal & $\begin{array}{l}34 \cdot 2 \\
31 \cdot 3 \\
39 \cdot 7 \\
32 \cdot 4 \\
30 \cdot 1 \\
34 \cdot 8 \\
33 \cdot 0 \\
35 \cdot 6 \\
35 \cdot 8 \\
32 \cdot 9\end{array}$ & $\begin{array}{l}24 \cdot 0 \\
21 \cdot 5 \\
29 \cdot 8 \\
25.5 \\
17 \cdot 1 \\
21 \cdot 1 \\
14 \cdot 8 \\
20 \cdot 8 \\
31 \cdot 6 \\
18 \cdot 4\end{array}$ & $\begin{array}{r}72 \cdot 1 \\
100 \cdot 0 \\
95 \cdot 4 \\
186 \cdot 5 \\
157 \cdot 2 \\
192 \cdot 0 \\
166 \cdot 8 \\
80 \cdot 0 \\
133 \cdot 7 \\
182 \cdot 0\end{array}$ & $\begin{array}{l}0.70 \\
0.69 \\
0.75 \\
0.79 \\
0.57 \\
0.61 \\
0.45 \\
0.58 \\
0.88 \\
0.56\end{array}$ \\
\hline Mean & 33.98 & $22 \cdot 44$ & $146 \cdot 57$ & 0.658 \\
\hline
\end{tabular}

* Ovarian wt divided by body wt $\times 1000$.

albino mice were subjected to bilateral olfactory bulb removal, while ten animals were left undisturbed. Seven weeks later, all mice were killed and their ovaries and uteri were weighed. The results are shown in Table 2. The ovaries of the bulbectomized animals were smaller than are those of the controls $(t=4 \cdot 14$, d.f. $=18, P<0 \cdot 005)$. There was no difference in uterine weight.

Thus, ovarian atrophy may have been a factor in limiting the number of pregnancies in the bulbectomized mice. In this respect, a species difference exists between the rat and the mouse. Olfactory bulb removal alone depresses the reproductive activity of the mouse; whereas, removal of a single sense 
(olfaction or vision) has no effect upon the reproductive tract or frequency of pregnancy in the rat (Reiter, Sorrentino \& Ellison, 1970; Orbach \& Kling, 1966) although the onset of puberty in the female is retarded (Orbach \& Kling, 1966).

The mechanism through which removal of the olfactory bulbs eliminates maternal behaviour is, at the present time, obscure. We have speculated elsewhere that the mouse may not be able to identify its young without discerning olfactory cues from them (Gandelman, Zarrow \& Denenberg, 1971). It is also possible that the olfactory system serves a non-olfactory function, the disruption of which will lead to an elimination of maternal behaviour.

This research was aided in part by Postdoctoral Fellowship HD-43413 from NICHD, NIH to R. Gandelman and by Research grant MH 19716, NIMH, to V. H. Denenberg and M. X. Zarrow. R. Gandelman is now at the Department of Psychology, Rutgers University.

\section{REFERENGES}

Aron, C., Ross, J. \& Asch, G. (1970) Effect of removal of the olfactory bulbs on mating behavior and ovulation in the rat. Neuroendocrinology, 6, 109.

BEACH, F. A. \& JAYNEs, J. (1956) Studies of maternal retrieving in rats. III. Sensory cues involved in the lactating female's response to her young. Behaviour, 10, 104.

Gandelman, R., Zarrow, M. X. \& Denenberg, V. H. (1971) Stimulus control of cannibalism and maternal behavior in anosmic mice. Physiol. Behav. 7, 583.

Gandelman, R., Zarrow, M. X., Denenberg, V. H. \& MYrers, M. (1971) Olfactory bulb removal eliminates maternal behavior in the mouse. Science, $\mathcal{N} . r .171,210$.

ORBACH, J. \& KLING, A. (1966) Effect of sensory deprivation on onset of puberty, mating fertility, and gonadal weights in rats. Brain Research, 3, 141.

ReIter, R. J., Sorrentino, S. \& Eilison, N. M. (1970) Interaction of photic and olfactory stimuli in mediating pineal-induced gonadal regression in adult female rats. Gen. EO Compar. Endocr. 15, 326.

Whitren, W. K. (1956) The effect of the removal of the olfactory bulbs on the gonads of mice. $\mathcal{J}$. Endocr. 14, 160.

Zarrow, M. X., Gandelman, R. \& Denenberg, V. H. (1971) Lack of nest building and maternal behavior in the mouse following olfactory bulb removal. Hormon. Behav. 2, 227. 